\title{
Macroeconomic risks and financial sector stability: the Nigerian case
}

\author{
Patrick Omoruyi Eke • B. Uzoma Achugamonu • \\ Simon Yunisa • Godswill Osagie Osuma $(\mathbb{C}$
}

(C) Indian Institute of Management Calcutta 2020

\begin{abstract}
This study examines the long-term effect of lending rate, exchange rate, inflation, institutional regulatory quality, budget deficit and gross domestic product on financial sector stability, proxied by the behavior of bank credit from 1981 to 2018. Using fully modified ordinary least square technique in an autoregressive distributive lag framework, non-performing loan is directly sensitive to lending rate, budget deficit, inflation rate and gross domestic product growth rate, but negatively related to exchange rate (a proxy for oil price) and institutions' regulatory quality. The study concludes that macroeconomic risks matter in the live of bank credit, and recommends reforms to promote financial health: focus on capital and securities markets for longtenured lending, credit market competitiveness to reduce lending rate; improved liberalization of foreign
\end{abstract}

P. O. Eke · B. U. Achugamonu - G. O. Osuma ( $\square)$

Department of Banking and Finance, Covenant University, Ota, Nigeria

e-mail: godswill.osuma@covenantuniversity.edu.ng

P. O. Eke

e-mail: patrick.eke@covenantuniversity.edu.ng

B. U. Achugamonu

e-mail: uzoma.achugamonu@covenantuniversity.edu.ng

P. O. Eke $\cdot$ S. Yunisa

Department of Banking and Finance, Lagos State

University, Ojo, Nigeria

e-mail: yunisasimon@yahoo.com exchange market; ease of doing business and economic inclusion to improve the growth rate.

Keywords Financial sector stability . Macroeconomic management - Oil price decline . Non-performing loans

JEL Classification $\mathrm{G} 10 \cdot \mathrm{E} 63$

\section{Introduction}

In the context of financial macroeconomics, an economy attains optimum outcome in resource allocation and growth when good policies crucial to promoting financial risk-taking attitude are enforced. In Nigeria and many developing economies however, these tasks may have been less optimized, such that, the quality of impact of the financial sector has often been subject of concern (Rousseau and D'Onofrio 2013; WEF 2017; World Bank 2016). Although, in line with public good, financial institutions indeed have responsibility for the transmission of monetary policies and other financial functions, quality macroeconomic policies matter (North 1991; Knoop 2013). The same argument applies for policy failure, as it is rear to find a single cause for the financial system's failure, but numbers of contributory factors (Ogunleye 2010; Heffernan 2005). Most studies in financial macroeconomic on Nigeria have explored the 